Journal for ImmunoTherapy of Cancer

\title{
Comparison of non-myeloablative lymphodepleting preconditioning regimens in patients undergoing adoptive $T$ cell therapy
}

\author{
Abraham Nissani, ${ }^{1}$ Shaked Lev-Ari, ${ }^{1}$ Tomer Meirson, ${ }^{1,2}$ Elad Jacoby, ${ }^{3,4}$ \\ Nethanel Asher (D) , ${ }^{1}$ Guy Ben-Betzalel, ${ }^{1}$ Orit Itzhaki, ${ }^{1}$ Ronnie Shapira-Frommer, ${ }^{1,5}$ \\ Jacob Schachter, ${ }^{1}$ Gal Markel, ${ }^{1,6}$ Michal J. Besser (i) ${ }^{1,6}$
}

To cite: Nissani A, Lev-Ari S, Meirson T, et al. Comparison of non-myeloablative lymphodepleting preconditioning regimens in patients undergoing adoptive T cell therapy. Journal for ImmunoTherapy of Cancer 2021;9:e001743. doi:10.1136/ jitc-2020-001743

- Additional material is published online only. To view, please visit the journal online (http://dx.doi.org/10.1136/jitc2020-001743).

AN, SL-A and TM contributed equally.

Accepted 19 March 2021

Check for updates

(c) Author(s) (or their employer(s)) 2021. Re-use permitted under CC BY-NC. No commercial re-use. See rights and permissions. Published by BMJ.

For numbered affiliations see end of article.

\section{Correspondence to} Dr Michal J. Besser; Michal.Besser@sheba.health. gov.il

\section{ABSTRACT}

Background Adoptive cell therapy with T cells genetically engineered to express a chimeric antigen receptor (CAR-T) or tumor-infiltrating T lymphocytes (TIL) demonstrates impressive clinical results in patients with cancer. Lymphodepleting preconditioning prior to cell infusion is an integral part of all adoptive T cell therapies. However, to date, there is no standardization and no data comparing different non-myeloablative (NMA) regimens.

Methods In this study, we compared NMA therapies with different doses of cyclophosphamide or total body irradiation (TBI) in combination with fludarabine and evaluated bone marrow suppression and recovery, cytokine serum levels, clinical response and adverse events.

Results We demonstrate that a cumulative dose of $120 \mathrm{mg} / \mathrm{kg}$ cyclophosphamide and $125 \mathrm{mg} / \mathrm{m}^{2}$ fludarabine (120Cy/125Flu) and 60Cy/125Flu preconditioning were equally efficient in achieving deep lymphopenia and neutropenia in patients with metastatic melanoma, whereas absolute lymphocyte counts (ALCs) and absolute neutrophil counts were significantly higher following 200 cGyTBI/75Flu-induced NMA. Thrombocytopenia was most profound in 120Cy/125Flu patients. 30Cy/75Flu-induced preconditioning in patients with acute lymphoblastic leukemia resulted in a minor ALC decrease, had no impact on platelet counts and did not yield deep neutropenia. Following cell infusion, $120 \mathrm{Cy} / 125 \mathrm{Flu}$ patients with objective tumor response had significantly higher ALC and significant lower inflammatory indexes, such as neutrophilto-lymphocyte ratio (NLR) and platelet-to-lymphocyte ratio (PLR). Receiver-operating characteristics curve analysis 7 days after cell infusion was performed to determine the cut-offs, which distinguish between responding and non-responding patients in the 120Cy/125Flu cohort. $\mathrm{NLR} \leq 1.79$ and $\mathrm{PLR} \leq 32.7$ were associated with clinical response and overall survival. Cytokine serum levels did not associate with clinical response in patients with TIL. Patients in the 120Cy/125Flu cohort developed significantly more acute NMA-related adverse events, including thrombocytopenia, febrile neutropenia and cardiotoxicity, and stayed significantly longer in hospital compared with the 60Cy/125Flu and TBI/75Flu cohorts. Conclusions Bone marrow depletion and recovery were equally affected by $120 \mathrm{Cy} / 125 \mathrm{Flu}$ and $60 \mathrm{Cy} / 125 \mathrm{Flu}$ preconditioning; however, toxicity and consequently duration of hospitalization were significantly lower in the $60 \mathrm{Cy} / 125 \mathrm{Flu}$ cohort. Patients in the $30 \mathrm{Cy} / 75 \mathrm{Flu}$ and TBI/75Flu groups rarely developed NMA-induced adverse events; however, both regimens were not efficient in achieving deep bone marrow suppression. Among the regimens, $60 \mathrm{Cy} / 125 \mathrm{Flu}$ preconditioning seems to achieve maximum effect with minimum toxicity.

\section{INTRODUCTION}

Adoptive cell therapy (ACT) has become a standard treatment option for patients with cancer. $\mathrm{T}$ cells genetically engineered to express a chimeric antigen receptor (CAR) against CD19 obtained FDA approval for acute lymphoblastic leukemia (ALL) and non-Hodgkin's lymphoma in 2017 and 2018. ${ }^{1}$ In addition, phase 2, phase 3 and pivotal studies of ACT with tumor-infiltrating lymphocytes (TILs) are currently conducted in patients with metastatic melanoma ${ }^{2-5}$ and other solid tumor types. ${ }^{6-9}$ A common feature of all current $\mathrm{T}$ cell therapies, no matter if they use gene engineered $\mathrm{T}$ cells or TIL, is the non-myeloablative (NMA) lymphodepleting preconditioning of patients prior to cell infusion.

It has been demonstrated that NMA preconditioning of the host with cyclophosphamide (Cy) and fludarabine (Flu) or total body irradiation $(\mathrm{TBI})^{10} 11$ enhances the survival, persistence and antitumor activity of the infused cells ${ }^{12}{ }^{13}$ by the elimination of regulatory $\mathrm{T}$ cells, increase of homeostatic cytokines like interleukin (IL)-7 and IL-15, and elimination of resident $\mathrm{T}$ cells competing for these trophic cytokines. ${ }^{13-16}$ Removal of cellular sinks, such as natural killer cells which compete for IL-7 and myeloid cells competing for IL-15, is required for proliferation and long-term survival of T cells. ${ }^{1517} 18$ 
Anthony et al demonstrated that IL-15 secretion, induced by inflammatory signals in response to lymphodepletion, drives CD8 T cell proliferation and promotes loss of tolerance against self-antigens, thereby enhancing the antitumor activity of T cells. ${ }^{19}$ In a small series, Kochenderfer et al reported that post lymphodepletion, high serum IL-15 levels are associated with remissions of patients with lymphoma receiving CAR-T cell therapy. ${ }^{18}$

NMA-induced bone marrow suppression and recovery can be monitored by measuring absolute lymphocyte, neutrophil and platelet counts in the blood of patients. Previously, we demonstrated that absolute lymphocyte counts (ALCs) 1 and 2 weeks post-TIL infusion were significantly correlated with objective response. ${ }^{2}$ In addition, others could show that a combination of cell counts, defined as inflammatory indexes, can be used as prognostic factors for survival in different types of cancers. ${ }^{20-23}$ For example, several studies have reported that a high neutrophil-to-lymphocyte ratio (NLR) and a high platelet-to-lymphocyte ratio (PLR) predict poor survival in patients with stage I-III melanoma, ${ }^{245}$ in patients with diffuse large $\mathrm{B}$ cell lymphoma treated with the immunochemotherapy combination R-CHOP (rituximab, cyclophosphamide, doxorubicin hydrochloride, vincristine and prednisone $)^{26}{ }^{27}$ and in patients with metastatic melanoma treated with checkpoint inhibitors ${ }^{28}$ or BRAF inhibitors. $^{29}$

Although there is a common consensus that NMA preconditioning is required to obtain a durable objective response in patients with cancer treated with adoptive $\mathrm{T}$ cell therapy, there is no study comparing the different NMA lymphodepleting regimens head-to-head.

Here, we systematically compare bone marrow suppression and recovery, the impact of NMA on inflammatory biomarkers, the effect on IL-15, IL-7 and IL-21 serum levels, and related adverse events following four different NMA therapies. In addition, we evaluate the impact of NMA on clinical response.

\section{MATERIAL AND METHODS \\ Patients}

Patients were enrolled to one of the three open-label, single arm, phase 2 trials. All patients were treated with $\mathrm{T}$ cell products manufactured in the same production facility at the Sheba Medical Center, as previously described. ${ }^{2} 930$ Patients signed an informed consent approved by the Israeli Ministry of Health.

Patients with stage IV melanoma were treated with TIL ACT as salvage therapy after failure of multiple treatments. The '120Cy/125Flu' cohort (NCT00287131) received NMA conditioning regimen with cyclophosphamide $(60 \mathrm{mg} / \mathrm{kg}$ for 2 days; days -7 and -6$)$ and fludarabine $\left(25 \mathrm{mg} / \mathrm{m}^{2}\right.$ for 5 days; days -5 to -1 ) before cell infusion (day 0) and the '60Cy/125Flu' cohort cyclophosphamide (30 $\mathrm{mg} / \mathrm{kg}$ for 2 days; days -5 and -4 ) and fludarabine $\left(25 \mathrm{mg} / \mathrm{m}^{2}\right.$ for 5 days; days -5 to -1 ) (NCT03166397). The 'TBI/75Flu' cohort received TBI
(200 cGy, on day -4) and fludarabine $\left(25 \mathrm{mg} / \mathrm{m}^{2}\right.$ for 3 days; days -3 to -1 ) (NCT03166397). TILs were administered intravenously, followed by high-dose bolus IL-2 with $720,000 \mathrm{IU} / \mathrm{kg} /$ dose, maximum of three times a day, for 5 days or up to tolerance. Patients received filgrastim for 7-10 days starting 1 day after cell infusion. Response was assessed using the Response Evaluation Criteria in Solid Tumors (RECIST V.1.1) guidelines 4 weeks following TIL administration and every 3 months thereafter or as clinically needed. Objective responders (ORs) were defined as complete and partial responders and non-responders (NRs) as patients with stable disease or progressive disease by determining the best overall response using RECIST.

Relapsed or refractory $(\mathrm{r} / \mathrm{r})$ pediatric and adult patients with ALL were treated with anti-CD19 CAR-T cells (NCT02772198). Lymphodepleting conditioning was induced by fludarabine $25 \mathrm{mg} / \mathrm{m}^{2}$ for 3 days (days -2 to -4 ) and cyclophosphamide $900 \mathrm{mg} / \mathrm{m}^{2}$ (which equals approximately $30 \mathrm{mg} / \mathrm{kg} \mathrm{Cy}$ ) for 1 day (day -2) (cohort ' $30 \mathrm{Cy} / 75 \mathrm{Flu}$ '), followed by infusion of $1 \times 10^{6}$ transduced CAR-T cells per kilogram weight. ${ }^{9}{ }^{31}$ Patients did not receive IL-2. For clinical evaluation of response, patients with ALL underwent a bone marrow aspiration 28 and 60 days following CAR-T cell administration, and disease assessment was performed by morphology, flow cytometry and PCR minimal residual disease based on immunoglobulin or T-cell receptor rearrangement, with a lower level of detection of 5-10 leukemia cells in 10,000-100,000 healthy cells.

\section{Cell counts and inflammatory indexes}

Absolute neutrophil, platelet and lymphocyte counts were obtained before NMA initiation and up to 3 months after cell infusion. The following inflammatory indexes were calculated: NLR, defined as neutrophil-tolymphocyte ratio; PLR, platelet-to-lymphocyte ratio; and systemic immune-inflammatory index (SII), defined as absolute neutrophil count $\times$ absolute platelet count/absolute lymphocyte count. All cell counts were performed in a centralized, automated laboratory at the Sheba Medical Center.

\section{Cytokine levels}

Patients' serum was collected on day 0 , before cell infusion. IL-7, IL-15 and IL-21 serum levels were determined by ELISA (IL-7, Human IL-7 Quantikine HS ELISA kit, R\&D Systems, Minneapolis, Minnesota, USA; IL-15 and IL-21, ELISA MAX Deluxe Set, BioLegend, San Diego, California, USA) according to the manufacturer's instructions. Measurements were performed in duplicates.

\section{Statistical analysis}

Significance of variation between groups was evaluated using a parametric two-tailed Student's t-test. The differences between proportions were tested using two-sided Fisher's exact test. Analysis of covariance was performed to examine differences in the mean values of patients' characteristics on variable production parameters. Cell 
Table 1 Patient cohorts

\begin{tabular}{|c|c|c|c|c|c|c|c|c|c|c|}
\hline \multirow[b]{2}{*}{ Cohort } & \multirow[b]{2}{*}{ ClinicalTrials identifier } & \multirow[b]{2}{*}{$\mathbf{N}$} & \multicolumn{2}{|c|}{ Cyclophosphamide } & \multicolumn{2}{|c|}{ Fludarabine } & \multicolumn{2}{|l|}{ TBI } & \multirow[b]{2}{*}{ Disease } & \multirow[b]{2}{*}{$\mathbf{T}$ cells } \\
\hline & & & $\mathrm{mg} / \mathrm{kg}$ & Days & $\mathrm{mg} / \mathrm{m}^{2}$ & Days & cGy & Days & & \\
\hline 120Cy/125Flu & NCT00287131 & 103 & $2 \times 60$ & -7 to -6 & $5 \times 25$ & -5 to -1 & - & & Melanoma & TIL \\
\hline TBI/75Flu & NCT03166397 & 9 & - & - & $3 \times 25$ & -3 to -1 & $1 \times 200$ & -4 & Melanoma & TIL \\
\hline 30Cy/75Flu & NCT02772198 & 19 & $1 \times \sim 30^{*}$ & -2 & $3 \times 25$ & -4 to -2 & - & & ALL & CAR-T \\
\hline
\end{tabular}

${ }^{*} 900 \mathrm{mg} / \mathrm{m}^{2}$.

ALL, acute lymphocytic leukemia; CAR-T, chimeric antigen receptor T cell; Cy, cyclophosphamide; Flu, fludarabine; TBI, total body irradiation; TIL, tumor-infiltrating T lymphocyte.

counts and inflammatory indexes were transformed to a logarithmic scale. Linear mixed models with Tukey's adjustment were used to compare absolute cell counts and inflammatory indexes between responder groups or the different regimens. Eastern Cooperative Oncology Group (ECOG) performance status was modeled as fixed effect. Effect sizes were calculated as Cohen's $d$. Linear mixed models were fit using the $\mathrm{R}$ statistical software ( www.r-project.org). The receiver-operating characteristics (ROC) curve analysis was used to define sensitivity and specificity through the Youden's index, and the area under the ROC curve (AUC) to find the optimal cut-off values for NLR, PLR and SII using the MedCalc V.18.11.6 (MedCalc Software). Survival curves were plotted by the Kaplan-Meier method, and differences between groups were assessed by the log-rank test using the Prism GraphPad V.8.0.1 (GraphPad Software).

\section{RESULTS \\ Cohorts}

Between 2005 and 2016, 103 patients with metastatic melanoma were enrolled to a phase 2 ACT trial with TIL following preconditioning with an accumulating dose of $120 \mathrm{mg} / \mathrm{kg}$ cyclophosphamide and $125 \mathrm{mg} / \mathrm{m}^{2}$ fludarabine $^{2}$ (120Cy/125Flu cohort; table 1). To analyze the impact of NMA on bone marrow suppression and recovery, absolute cell counts were collected, starting a few days before NMA initiation (baseline) and up to 3 months post therapy. Due to cyclophosphamide-induced toxicity (detailed later), a follow-up study was initiated. The cyclophosphamide dose was halved (60Cy/125Flu) or cyclophosphamide was replaced with $200 \mathrm{cGy}$ TBI (table 1). In 2017 and 2018, nine patients with metastatic melanoma were enrolled to the TBI/75Flu group, and in 2019 and 2020, eight patients received 60Cy/125Fluinduced NMA. Patients in the $60 \mathrm{Cy} / 125 \mathrm{Flu}$ cohort and those in the TBI/75Flu cohort did not respond to TIL therapy. The TIL manufacturing procedure was identical in all three cohorts. TILs were manufactured at the same Good Manufacturing Practice (GMP) facility and by the same staff.

The three melanoma cohorts were well matched for most baseline characteristics (eg, ECOG performance status) but were significantly different with respect to prior treatments (table 2). Most patients in the 120Cy/125Flu cohort were treated in the pre-immune checkpoint inhibitor (pre-ICI) era, whereas patients in the $60 \mathrm{Cy} / 125 \mathrm{Flu}$ and TBI/75Flu cohorts were all treated after treatment failure with ICIs.

Simultaneously, CD19 CAR-T therapy was conducted at our clinical center and both TIL and CAR-T were produced at the same GMP cell production facility. Between 2016 and 2019, patients with $\mathrm{r} / \mathrm{r}$ ALL were treated with CD19 CAR-T cells following NMA with fludarabine and cyclophosphamide $900 \mathrm{mg} / \mathrm{m}^{2}$ (which equals approximately $30 \mathrm{mg} / \mathrm{kg} \mathrm{Cy}$ ) ('30Cy/75Flu' cohort). Absolute cell counts were acquired from 19 patients, including 13 complete responders and 6 NRs. The patients received, on average, $4.0 \pm 1.2$ prior treatments and 2 of 19 (11\%) patients had brain metastasis. The 30Cy/125Flu ALL cohort included pediatric patients, thus the average age was low in this cohort. Since patients in the $30 \mathrm{Cy} / 125 \mathrm{Flu}$ cohort had a different underlying disease and were treated with CAR-T cells instead of TIL, the results of this cohort will be demonstrated separately.

\section{Bone marrow suppression}

To evaluate the impact of the different preconditioning regimens on bone marrow suppression, absolute cell counts were monitored in the three melanoma groups (figure 1) and the ALL cohort (discussed later). Cell counts were performed in a centralized, automated laboratory. The number of patients with available cell counts per day is shown in online supplemental table 1 . The day of cell infusion was defined as 'day 0'.

One hundred and one of $103(98 \%)$ patients in the $120 \mathrm{Cy} / 125 \mathrm{Flu}$ and $100 \%$ (8 of 8 ) patients in the $60 \mathrm{Cy} / 125 \mathrm{Flu}$ cohort achieved severe neutropenia, defined as absolute neutrophil count $(\mathrm{ANC}) \leq 0.5 \mathrm{~K} / \mu \mathrm{L}$. The lowest values of ANC were found 3 days after cell infusion in the $120 \mathrm{Cy} / 125 \mathrm{Flu}$ group $(0.065 \pm 0.230 \mathrm{~K} /$ $\mu \mathrm{L}$; median $0.025 \mathrm{~K} / \mu \mathrm{L}$ ) and 4 days after cell infusion in the $60 \mathrm{Cy} / 125 \mathrm{Flu}$ cohort $(0.050 \pm 0.044 \mathrm{~K} / \mu \mathrm{L}$; median $0.030 \mathrm{~K} / \mu \mathrm{L}) \quad(\mathrm{p}=0.871) \quad$ (figure $1 \mathrm{~A}$, table 3 and online supplemental figure 1). TBI/75Flu preconditioning did not result in severe neutropenia and the lowest value was $1.088 \pm 0.541 \mathrm{~K} / \mu \mathrm{L}$ (median $1.100 \mathrm{~K} / \mu \mathrm{L}$ ) 1 month after cell infusion. In contrast, five of nine $(56 \%)$ patients in the $\mathrm{TBI} / 75 \mathrm{Flu}$ cohort demonstrated even a sharp 
Table 2 Baseline and treatment characteristics of the three metastatic melanoma cohorts

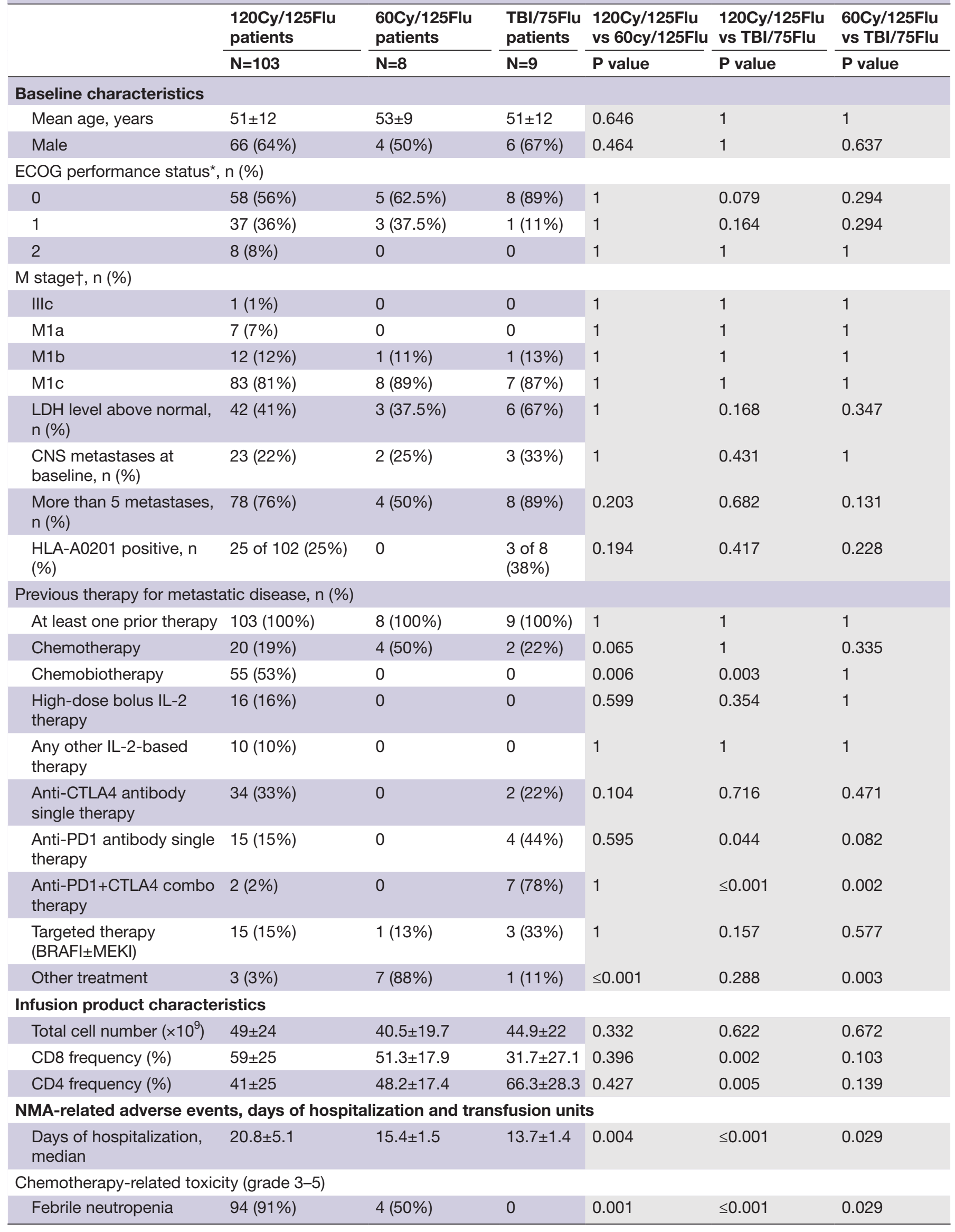


Table 2 Continued

\begin{tabular}{|c|c|c|c|c|c|c|}
\hline & $\begin{array}{l}120 \mathrm{Cy} / 125 \mathrm{Flu} \\
\text { patients }\end{array}$ & $\begin{array}{l}60 \mathrm{Cy} / 125 \mathrm{Flu} \\
\text { patients }\end{array}$ & $\begin{array}{l}\text { TBI/75Flu } \\
\text { patients } \\
\end{array}$ & $\begin{array}{l}120 \mathrm{Cy} / 125 \mathrm{Flu} \\
\text { vs } 60 \mathrm{cy} / 125 \mathrm{Flu} \\
\end{array}$ & $\begin{array}{l}\text { 120Cy/125Flu } \\
\text { vs TBI/75Flu } \\
\end{array}$ & $\begin{array}{l}60 \mathrm{Cy} / 125 \mathrm{Flu} \\
\text { vs TBI/75Flu }\end{array}$ \\
\hline & $N=103$ & $N=8$ & $\mathbf{N}=9$ & $P$ value & $P$ value & $P$ value \\
\hline $\begin{array}{l}\text { Fatal myelodysplastic } \\
\text { syndrome }\end{array}$ & $1(1 \%)$ & 0 & 0 & 1 & 1 & 1 \\
\hline \multicolumn{7}{|l|}{ Transfusion data } \\
\hline No of RC units, average & $4.7 \pm 5.8$ & $0.63 \pm 0.92$ & 0 & 0.055 & 0.019 & 0.057 \\
\hline No of PLT units, average & $24.8 \pm 35.4$ & 0 & 0 & 0.051 & 0.039 & 1 \\
\hline
\end{tabular}

${ }^{*}$ ECOG Eastern Cooperative Oncology Group (ECOG) status ranges from 0 to 5 , with higher scores indicating greater impairment $(5$ indicates death).

†The metastasis (M) stage was classified according to the tumor-node-metastasis (TNM) categorization for melanoma of the American Joint Committee on Cancer.

CNS, central nervous system; CTLA4, cytotoxic T-lymphocyte-associated protein 4; Cy, cyclophosphamide; Flu, fludarabine; HLA, human leukocyte antigen; IL, interleukin; LDH, lactate dehydrogenase; NMA, non-myeloablative; PD1, Programmed cell death protein 1; PLT, platelets; RC, red cells; TBI, total body irradiation.

increase of ANC, with values between 13.03 and $16.13 \mathrm{~K} /$ $\mu \mathrm{L} 1$ day after cell infusion when the normal range for neutrophils is between 1.8 and $7.7 \mathrm{~K} / \mu \mathrm{L}$ (figure $1 \mathrm{~A}$ ).

Similar results were observed for ALC (figure $1 \mathrm{~B}$ and table 3). $120 \mathrm{Cy} / 125 \mathrm{Flu}$ and $60 \mathrm{Cy} / 125 \mathrm{Flu}$ preconditioning were equally effective in achieving deep lymphodepletion, with lowest average values of $0.029 \pm 0.036 \mathrm{~K} /$ $\mu \mathrm{L} \quad($ median $0.020 \mathrm{~K} / \mu \mathrm{L}$ ) and $0.024 \pm 0.017 \mathrm{~K} / \mu \mathrm{L}$ (median $0.025 \mathrm{~K} / \mu \mathrm{L}$ ) on the day of cell infusion in the $120 \mathrm{Cy} / 125 \mathrm{Flu}$ and $60 \mathrm{Cy} / 125 \mathrm{Flu}$ cohorts, respectively $(\mathrm{p}=0.389)$, when normal values are between 1.0 and $4.8 \mathrm{~K} /$ $\mu \mathrm{L}$. A direct comparison of the ALC in the $120 \mathrm{Cy} / 125 \mathrm{Flu}$ and $60 \mathrm{Cy} / 125 \mathrm{Flu}$ cohorts over time is shown in figure 1D. Administration of cyclophosphamide in the $120 \mathrm{Cy} / 125 \mathrm{Flu}$ cohort was initiated on day -7 and in $60 \mathrm{Cy} / 125 \mathrm{Flu}$ cohort on day -5 , which explains the difference of ALC on days -4 and -3 . In the TBI/Flu cohort, only a minor decrease in ALC was achieved (lowest value: $0.062 \pm 0.046 \mathrm{~K} / \mu \mathrm{L}$; median $0.050 \mathrm{~K} / \mu \mathrm{L}$; on day +1 ) (figure $1 \mathrm{~B}$ ). Lymphodepletion was significantly less efficient compared with the $120 \mathrm{Cy} / 125 \mathrm{Flu}$ and $60 \mathrm{Cy} / 125 \mathrm{Flu}$ cohorts (p values $\leq 0.01$; figure $1 \mathrm{E}$ and $\mathrm{F}$ ).

Platelet counts at baseline were normal in the three melanoma cohorts $(120 \mathrm{Cy} / 125 \mathrm{Flu}$ cohort, $281 \pm 96 \mathrm{~K} / \mu \mathrm{L}$; $60 \mathrm{Cy} / 125 \mathrm{Flu}$ cohort, $341 \pm 121 \mathrm{~K} / \mu \mathrm{L}$; TBI/75Flu cohort, $299 \pm 82 \mathrm{~K} / \mu \mathrm{L}$ ). In the $120 \mathrm{Cy} / 125 \mathrm{Flu}$ and $60 \mathrm{Cy} / 125 \mathrm{Flu}$ cohorts, an APC decrease was observed following NMA initiation; however, in the $120 \mathrm{Cy} / 125 \mathrm{Flu}$ cohort, values were significantly lower $(120 \mathrm{Cy} / 125 \mathrm{Flu}$, lowest value $34 \pm 26 \mathrm{~K} / \mu \mathrm{L}$, median $26 \mathrm{~K} / \mu \mathrm{L} ; 60 \mathrm{Cy} / 125 \mathrm{Flu}$ cohort, lowest value $115 \pm 51 \mathrm{~K} / \mu \mathrm{L}$, median $103 \mathrm{~K} / \mu \mathrm{L} ; \mathrm{p} \leq 0.001$ ) (figure $1 \mathrm{C}$ and online supplemental figure $1 \mathrm{D}-\mathrm{F}$ ).
In conclusion, $120 \mathrm{Cy} / 125 \mathrm{Flu}$ and $60 \mathrm{Cy} / 125 \mathrm{Flu}$ preconditioning were equally efficient in achieving deep lymphopenia and neutropenia, which was not the case for TBI/75Flu NMA.

\section{Bone marrow recovery}

Both in the 120Cy/125Flu and 60Cy/125Flu cohorts, the patients recovered by day 6 and day 7 from their severe neutropenia, and counts within the norm $(1.8-7.7 \mathrm{~K} / \mu \mathrm{L})$ were measured (120Cy/125Flu cohort, $3.63 \pm 5.22 \mathrm{~K} / \mu \mathrm{L}$, median $1.54 \mathrm{~K} / \mu \mathrm{L} ; 60 \mathrm{Cy} / 125 \mathrm{Flu}$ cohort, $3.01 \pm 2.03 \mathrm{~K} / \mu \mathrm{L}$, median $2.73 \mathrm{~K} / \mu \mathrm{L}$ ) (figure $1 \mathrm{~A}$ ).

Interestingly, although TBI/75Flu-induced NMA caused a sharp increase of ANC 1 day after cell infusion followed by mild neutropenia, neutrophil recovery was delayed and baseline levels were only reached after 1 month.

Recovery of ALC was observed in all the cohorts 4-7 days after cell infusion and returned to the normal range of values (figure 1B). The duration of severe lymphopenia was 7 days in the 120Cy/125Flu and 60Cy/125Flu cohorts, but only 2 days in the TBI/75Flu cohort.

Platelet recovery was found 12-14 days after cell infusion in the $120 \mathrm{Cy} / 125 \mathrm{Flu}$ cohort. In the TBI/75Flu cohort, APC steadily decreased over time and $50 \%$ (three out of six) of the patients had prolonged thrombocytopenia around 3 weeks after cell infusion (figure 1C).

\section{Impact of NMA on clinical response}

To evaluate if bone marrow suppression and recovery can serve as predictive markers of clinical response, we analyzed the cell counts in the 120Cy/125Flu melanoma patient cohort (ORs, $\mathrm{N}=29$; NRs, $\mathrm{N}=74$ ). The baseline 
A

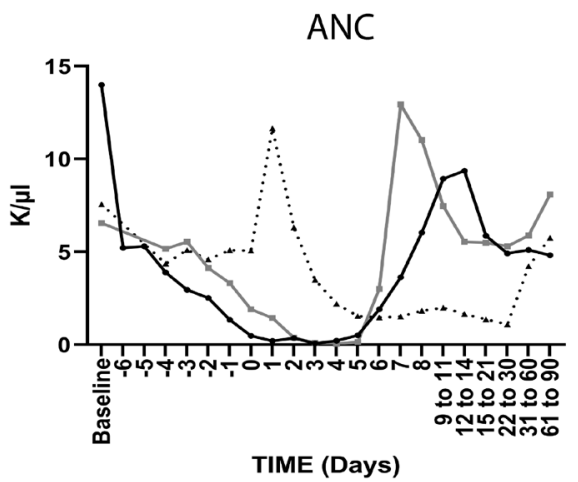

D

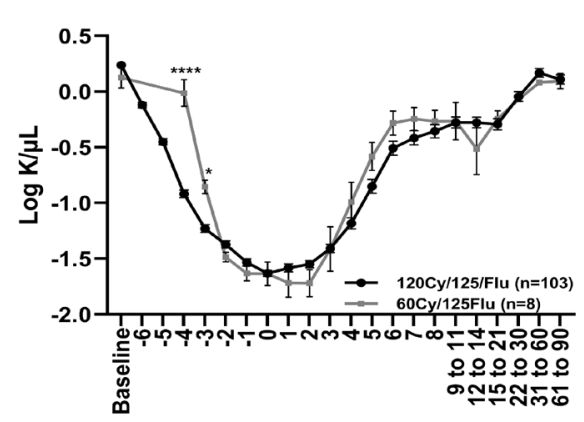

TIME (Days)
B

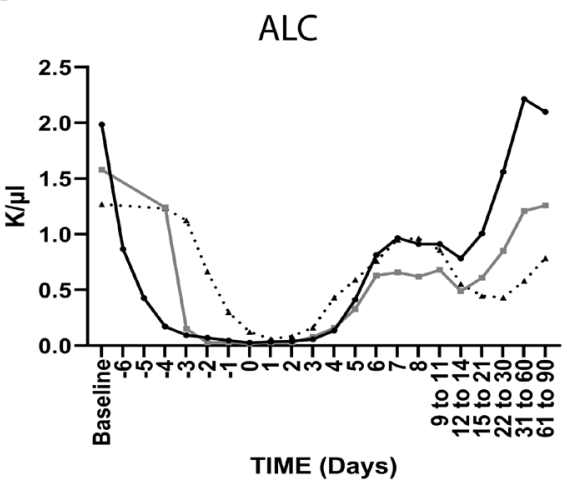

$\rightarrow 120$ Cy/125/Flu $(n=103)$

- 60Cy/125Flu $(n=8)$

... TBI/75Flu ( $n=9)$

E

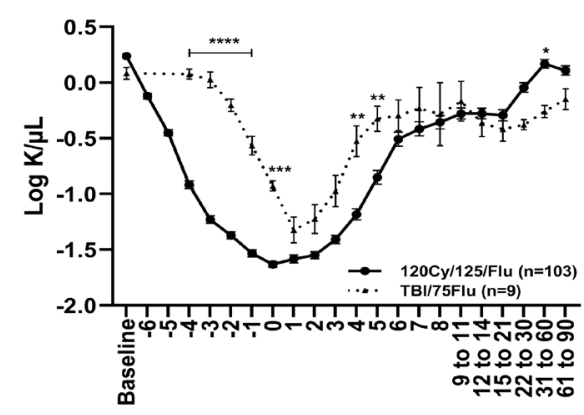

C

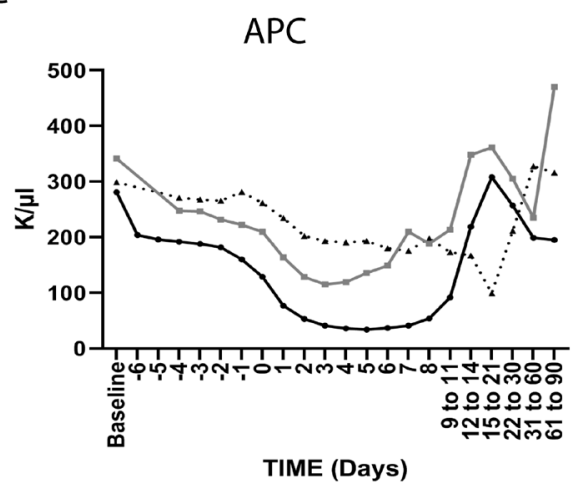

F

ALC

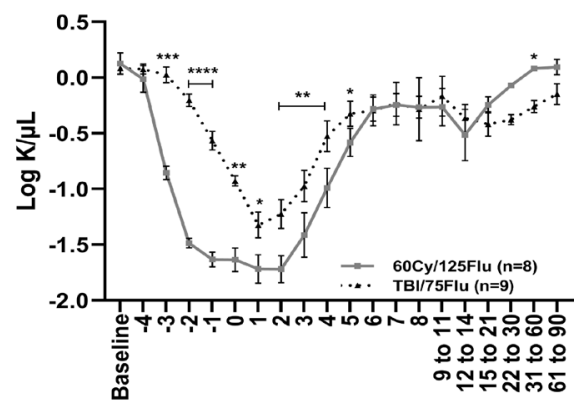

TIME (Days)

Figure 1 Cell counts following non-myeloablative lymphodepletion. (A) Absolute neutrophil count (ANC), (B) absolute lymphocyte count (ALC) and (C) absolute platelet count (APC). (D-F) Comparison of ALC between (D) the 120Cy/175Flu and $60 \mathrm{Cy} / 175 \mathrm{Flu}$ cohorts, (E) the 120Cy/175Flu and TBI/75Flu cohorts and (F) the 60Cy/125Flu and TBI/75Flu cohorts. Day 0 , day of cell infusion. ${ }^{*} \mathrm{p}<0.05,{ }^{* *} \mathrm{p}<0.01,{ }^{* * *} \mathrm{p}<0.001$ and ${ }^{* * * *} \mathrm{p}<0.0001$. Cy, cyclophosphamide; Flu, fludarabine; TBI, total body irradiation.

characteristics of responders and non-responders were previously reported and multivariate logistic regression revealed that ECOG performance status was an independent factor of response in this cohort. ${ }^{2}$

Responding and non-responding patients had similar ANC, ALC and APC at baseline $(\mathrm{p}=0.953, \mathrm{p}=0.497$ and $\mathrm{p}=0.343$ ) (figure 2A-C). Following NMA initiation, there was no significant difference between responders and non-responders regarding ANC $(\mathrm{d}=0.083, \mathrm{p}=0.508)$ (figure 2A) and APC ( $\mathrm{d}=0.007, \mathrm{p}=0.972$ ) (figure 2C). However, ALCs were significantly different $(d=0.605$, $\mathrm{p}=\leq 0.001$ ) (figure 2B). From day 4 onwards, OR patients had significantly higher lymphocyte counts, with the highest significant difference between days 5 and 21 ( $p$ values $\leq 0.001)$. Absolute cell counts were further compared between ORs $(\mathrm{N}=29)$ and $\mathrm{NRs}(\mathrm{N}=29)$, which were matched for baseline characteristics, including ECOG and prior treatments (online supplemental figure

Table 3 Lowest values of absolute cell counts

\begin{tabular}{|c|c|c|c|c|c|c|c|c|c|}
\hline & \multicolumn{3}{|l|}{ 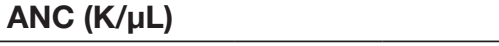 } & \multicolumn{3}{|l|}{ ALC $(K / \mu L)$} & \multicolumn{3}{|l|}{ APC $(K / \mu L)$} \\
\hline \multirow[t]{3}{*}{ Normal level } & $1.8-7.7$ & & & $1.0-4.8$ & & & $130-440$ & & \\
\hline & \multicolumn{2}{|l|}{ Lowest value } & \multirow[b]{2}{*}{ Day } & \multicolumn{2}{|l|}{ Lowest value } & \multirow[b]{2}{*}{ Day } & \multicolumn{2}{|l|}{ Lowest value } & \multirow[b]{2}{*}{ Day } \\
\hline & Average \pm SD & Median & & Average $\pm S D$ & Median & & Average $\pm S D$ & Median & \\
\hline 120Cy/125Flu & $0.065 \pm 0.230$ & 0.025 & 3 & $0.029 \pm 0.036$ & 0.020 & 0 & $34 \pm 26$ & 26 & 5 \\
\hline 60Cy/125Flu & $0.050 \pm 0.044$ & 0.030 & 4 & $0.024 \pm 0.017$ & 0.025 & 0 & $115 \pm 51$ & 103 & 3 \\
\hline TBI/75Flu & $1.088 \pm 0.541$ & 1.100 & $22-30$ & $0.062 \pm 0.046$ & 0.050 & 1 & $99 \pm 51$ & 91 & $15-21$ \\
\hline
\end{tabular}

ALC, absolute lymphocyte count; ANC, absolute neutrophil count; APC, absolute platelet count; Cy, cyclophosphamide; Flu, fludarabine; TBI, total body irradiation. 


\section{Cy/125Flu cohort}

A

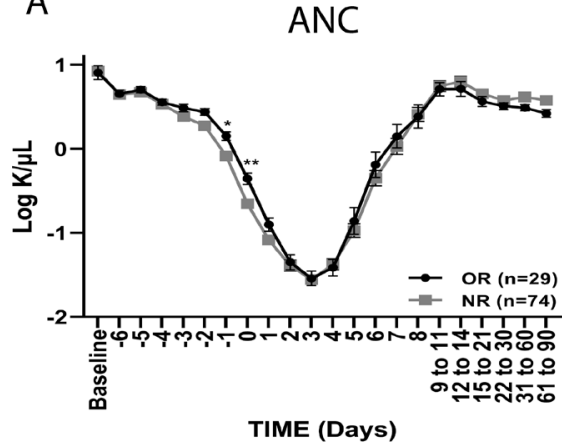

D

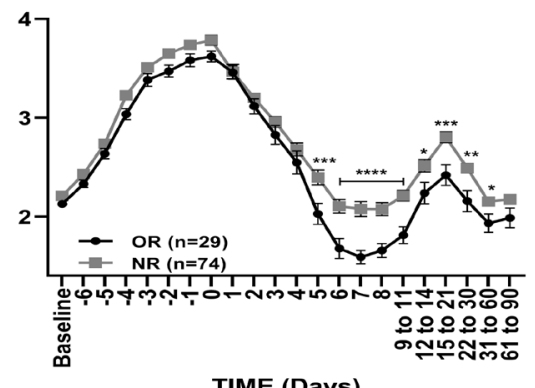

B

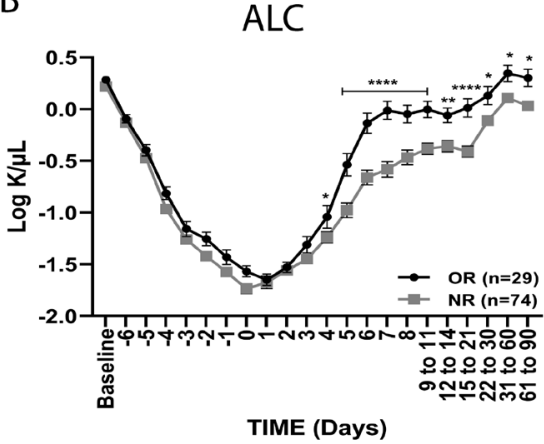

E

NLR

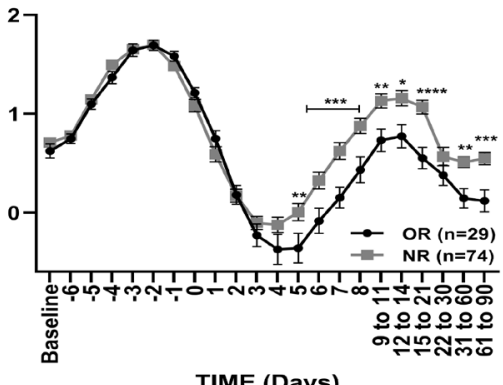

C

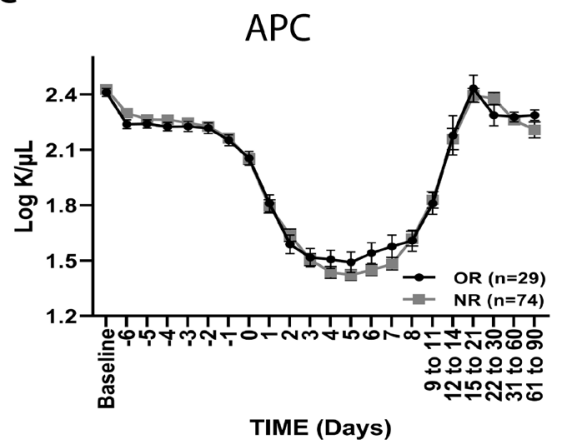

F

Figure 2 Absolute cell counts and inflammatory ratios of responders and non-responders in the 120Cy/125Flu cohort. (A) Absolute neutrophil count (ANC), (B) absolute lymphocyte count (ALC) and (C) absolute platelet count (APC), (D) platelet-toneutrophil ratio (PLR), (E) neutrophil-to-lymphocyte ratio (NLR) and (F) systemic immune-inflammatory index (SII) of objective responders (ORs) and non-responders (NRs). Data are shown as mean \pm SEM. ${ }^{*} p<0.05,{ }^{\star \star} p<0.01,{ }^{* \star *} p<0.001$ and ${ }^{\star \star \star \star} p<0.0001$. Cy, cyclophosphamide (Cy); Flu, fludarabine.

2A-C), as well as the entire cohort, excluding patients with ECOG 2 and prior anti-PD1 therapy (OR, N=28; NR, $\mathrm{N}=53$ ) (online supplemental figure 2D-F) and demonstrated the same results.

\section{Inflammatory indexes as prognostic factors for response and overall survival in the $120 \mathrm{Cy} / 125$ Flu melanoma cohort}

It was shown that the combination of absolute cell counts, defined as inflammatory indexes, can be used as a prognostic factor for response and survival in different types of cancer and may be more significant than individual counts. ORs in the 120Cy/125Flu melanoma cohort had significantly lower PLR, NLR and SII from day 5 onwards (figure 2D).

ROC curves were used to obtain the optimal inflammatory indexes cut-offs on day 7 , which distinguish between ORs and NRs. The optimal cut-off for NLR was 1.79, for PLR 32.7 and for SII $368 \mathrm{~K} / \mu \mathrm{L}$.

We found that $61 \%$ ( 17 of 28 ) of OR patients compared with $24 \%$ (16 of 66 ) of NR patients had an NLR $\leq 1.79$ $(p=0.002)$ and $61 \%$ ( 17 of 28$)$ of the responders compared with $15 \%$ of the NRs had a PLR $\leq 32.7(p \leq 0.001)$. SII on day 7 could not be used to distinguish between OR and NR patients.

Kaplan-Meier analysis indicated that lower values of NLR and PLR were also significantly associated with prolonged overall survival (OS) in the $120 \mathrm{Cy} / 125 \mathrm{Flu}$ cohort. As shown in figure 3, patients with NLR $\leq 1.79$ had a median OS of 23 months compared with 13.5 months for patients with NLR>1.79 months ( $\mathrm{p}=0.011)$; patients with $\mathrm{PLR} \leq 32.7$ had a median OS of 39 months compared with 12.5 months for patients with PLR $>32.7(\mathrm{p}=\leq 0.001)$.

\section{Impact of NMA on IL-7, IL-15 and IL-21 serum levels}

To determine the impact of the different lymphodepleting regimens on cytokine levels, ELISA assays were performed with serum samples collected after completion of NMA and before cell infusion (day 0). Serum was available from patients with melanoma in the 120Cy/125Flu cohort ( $\mathrm{N}=24$, including 12 ORs and 12 NRs), $60 \mathrm{Cy} / 125$ Flu cohort $(\mathrm{N}=7)$ and $\mathrm{TBI} / 75$ Flu cohort $(\mathrm{N}=8)$.

IL-7 serum levels were significantly lower following TBI/75Flu-induced lymphodepletion compared with $120 \mathrm{Cy} / 125 \mathrm{Flu}$ NMA (TBI/75Flu cohort, $12.0 \pm 7.0 \mathrm{pg} /$ $\mathrm{mL} ; 120 \mathrm{Cy} / 125 \mathrm{Flu}$ cohort, $19.0 \pm 5.7 \mathrm{pg} / \mathrm{mL} ; \mathrm{p}=0.008$ ) (figure 4A). IL-15 serum levels were insignificantly different in all three cohorts (figure 4B). Patients in the $60 \mathrm{Cy} / 125 \mathrm{Flu}$ cohort had significantly higher IL-21 serum levels $(240 \pm 116 \mathrm{pg} / \mathrm{mL})$ than patients from the TBI/75Flu cohort $(122 \pm 101 \mathrm{pg} / \mathrm{mL} ; \mathrm{p}=0.048)$ and $120 \mathrm{Cy} / 125 \mathrm{Flu}$ cohort $(124 \pm 71 \mathrm{pg} / \mathrm{mL} ; \mathrm{p}=0.002)$ (figure $4 \mathrm{C})$. 

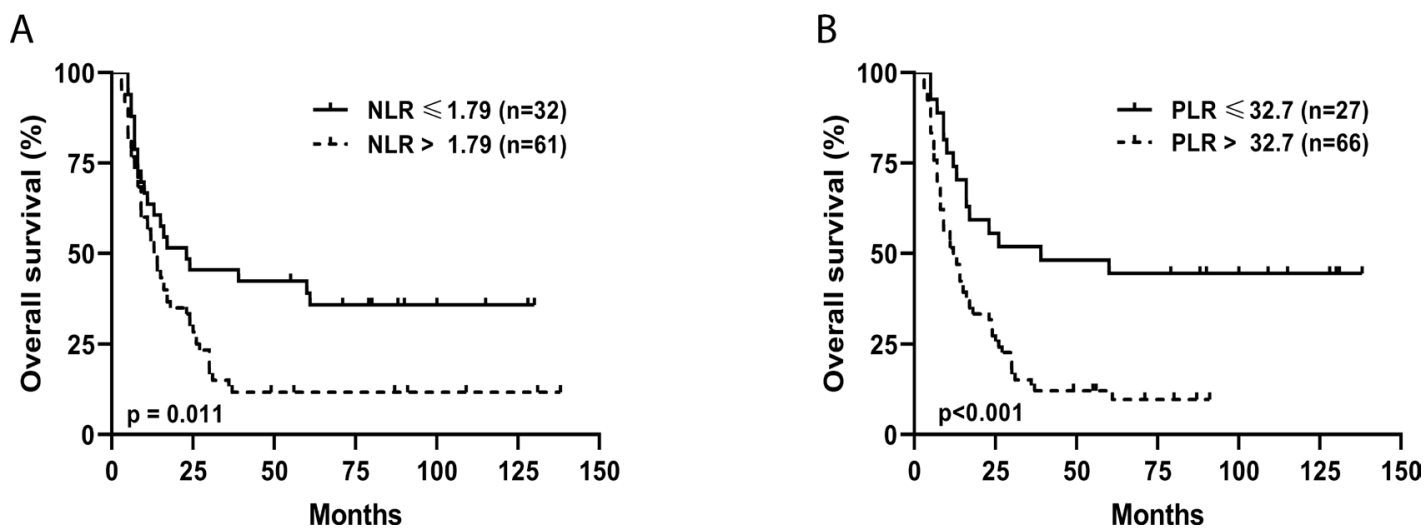

Figure 3 Kaplan-Meier curves for assessment of median overall survival. Kaplan-Meier curves for the inflammatory indexes (A) NLR and (B) PLR according to cut-off values received by ROC curve analysis. Survival analysis was performed by the log-rank test. ROC, Receiver operating characteristics; NLR, neutrophil-to-lymphocyte ratio; PLR, platelet-to-lymphocyte ratio; .

A
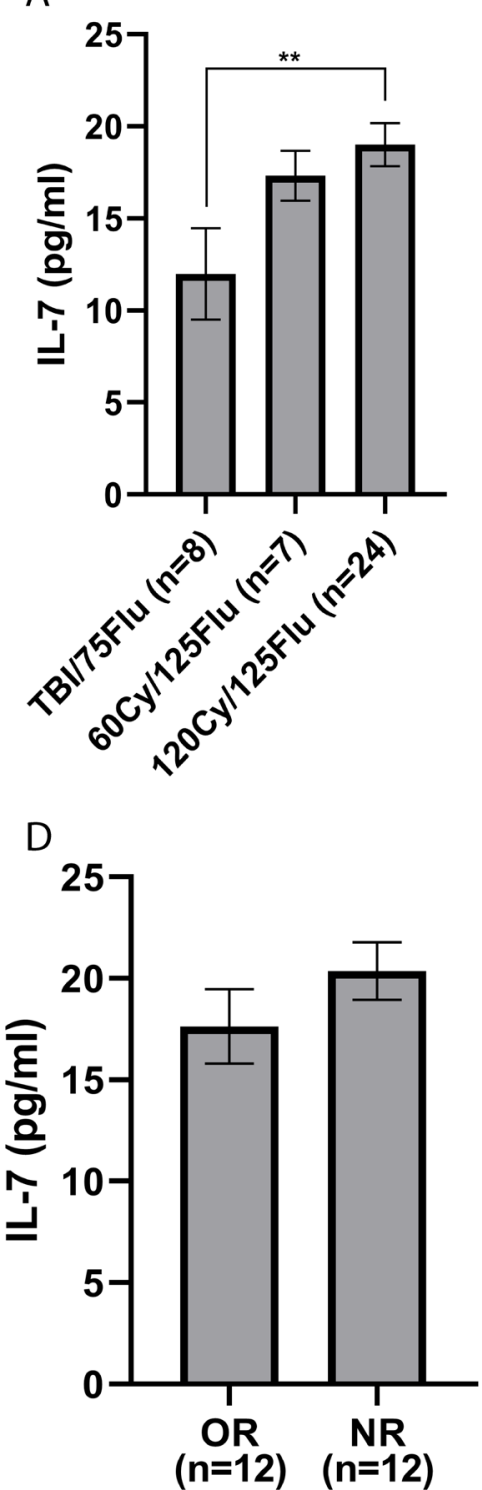

B

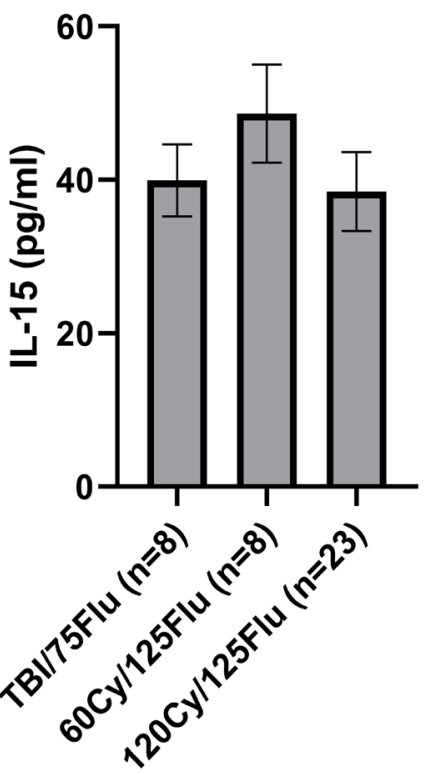

E

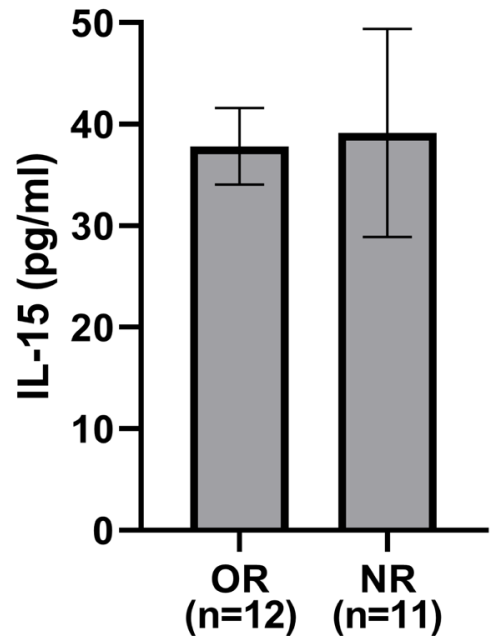

C
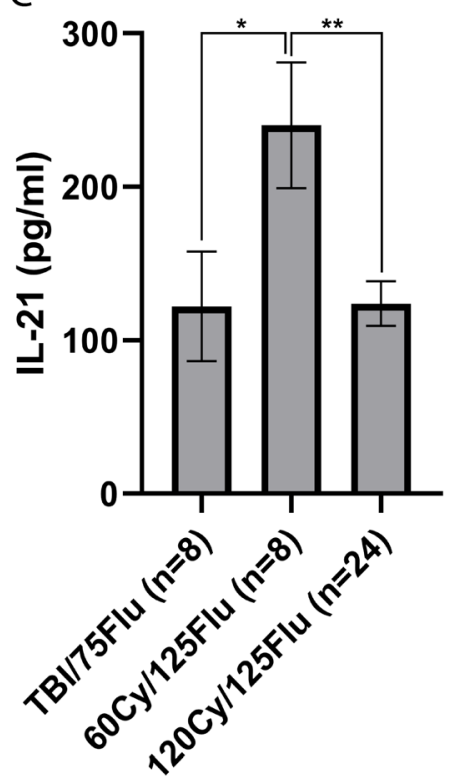

$\mathrm{F}$

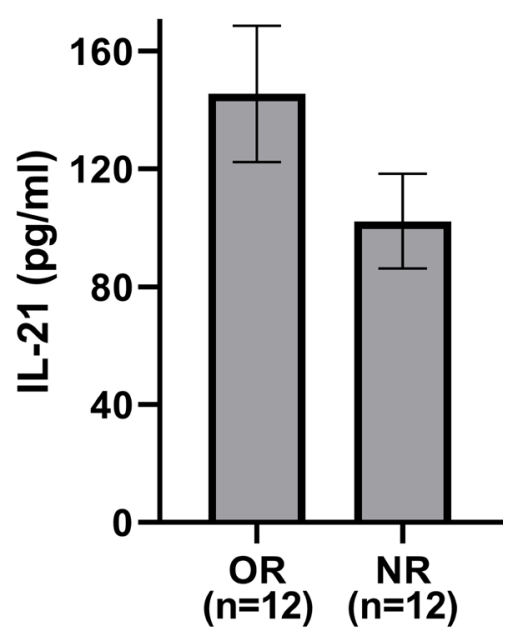

Figure 4 Cytokine serum levels on the day of cell infusion. (A) IL-7, (B) IL-15 and (C) IL-21. (D-F) Comparison of cytokine serum levels between objective responders (ORs) and non-responders (NRs) in the 120Cy/125Flu cohort. Data are shown as mean \pm SEM analyzed using a non-parametric two-tailed Student's t-test. ${ }^{*} p<0.05$ and ${ }^{* *} p<0.01$. Cy, cyclophosphamide; Flu, fludarabine; IL, interleukin; TBI, total body irradiation. 
No significant differences between IL-7 ( $\mathrm{p}=0.252)$, IL-15 ( $\mathrm{p}=0.902)$ and IL-21 $(\mathrm{p}=0.140)$ serum levels were observed between ORs $(\mathrm{N}=12)$ and $\mathrm{NRs}(\mathrm{N}=12)$ in the 120Cy/125Flu cohort (figure 4D).

\section{NMA-related toxicity}

\section{Cy/125Flu cohort}

The NMA, TIL and high-dose IL-2 toxicity profiles in the $120 \mathrm{Cy} / 125 \mathrm{Flu}$ cohort were recently published. ${ }^{2}$ Table 2 shows NMA-related adverse events. In short, most $120 \mathrm{Cy} / 125$ Flu-related toxicities were manageable, while the most common adverse effect was acute grade 3-4 neutropenic fever affecting 91\% (94 of 103) of the patients. Administration of high-dose cyclophosphamide at a dose of $60 \mathrm{mg} / \mathrm{kg}$ for 2 days required antiemetic treatment adjusted for high emetogenic-risk chemotherapy, yet steroid treatment was avoided. The use of antiemetics during days -7 to -5 of hospitalization (starting prior to the cyclophosphamide infusion) increased the level of tolerability of the infusion of high-dose cyclophosphamide chemotherapy. Mild nausea, jaw discomfort or headaches during infusion were the most commonly reported immediate side effects. No hemorrhagic cystitis was noted. No acute drug-related side effects were found to be correlated with the infusion of fludarabine for 5 days . Patients reported lack of appetite, mild nausea and fatigue. Ninety-one of $103(88 \%)$ and 79 of 102 $(77 \%)$ patients required red cells (RCs) (4.7 \pm 5.8 units) and/or platelet (PLT) transfusions (24.8 \pm 35.4 units) to prevent complications from anemia or bleeding. The average duration of hospitalization from NMA admission to discharge was $20.8 \pm 5.1$ days.

Of note, there were three cases of early deaths, all considered to be related to cyclophosphamide induced cardiotoxicity. All cases presented with symptoms of acute heart failure before TIL infusion. High-dose cyclophosphamide is known to cause cardiotoxicity in $7 \%-28 \%$ of patients and cyclophosphamide-induced mortality has been described in $11 \%-43 \%$ of patients at a dose of $170-180 \mathrm{mg} / \mathrm{kg}^{32}$

As for late toxicity of chemotherapy, one patient developed papillary thyroid cancer 3.5 years after TIL therapy, which was successfully treated surgically, and one patient was diagnosed with myelodysplastic syndrome followed by acute leukemia 4.5 years after therapy.

\section{Cy/125Flu cohort}

Due to the high-dose cyclophosphamide-induced toxicities, we investigated the possibility of reducing or replacing cyclophosphamide. $60 \mathrm{Cy} / 125$ Flu-related toxicities are detailed in table 2. Decreasing the cyclophosphamide doses from $2 \times 60 \mathrm{mg} / \mathrm{kg}$ (120Cy) to $2 \times 30 \mathrm{mg} /$ $\mathrm{kg}$ (60Cy) resulted in a significantly lower number of cases with grade 3-4 febrile neutropenia (60Cy/125Flu cohort, $50 \%$ vs $91 \%$, 120Cy/125 Flu cohort; $\mathrm{p}=0.001$ ) and shorter time of hospitalization ( $15.4 \pm 1.5$ days vs $20.8 \pm 5.1 ; \mathrm{p}=0.004)$. Three of eight patients developed anemia, which required $\mathrm{RC}$ transfusions $(0.63 \pm 0.92$ units vs $4.7 \pm 5.8$ units; $\mathrm{p}=0.055$ ) and no patient experienced thrombocytopenia, which required transfusion of platelets $(\mathrm{p}=0.039)$. There was no fatality.

\section{TBI/75Flu cohort}

Acute toxicities were in general considerably mild in this cohort, which is reflected in a significantly shorter hospital stay (TBI/75Flu cohort 13.7 $\pm 1.4,120 \mathrm{Cy} / 125 \mathrm{Flu}$ cohort $20.8 \pm 5$.1 days; $\mathrm{p} \leq 0.001$ ) (table 2 ). No patient in the TBI/75Flu cohort experienced chemotherapy-related febrile neutropenia and no patient required RC and PLT transfusions.

\section{Cy/75Flu ALL cohort}

The 30Cy/75Flu cohort differed in many aspects from the other three cohorts. Patients in the 30Cy/75Flu group suffered from ALL (instead of metastatic melanoma), were treated with CAR-T (instead of TIL), did not receive IL-2 administration following infusion (instead of highdose bolus IL-2) and received prior lines of chemotherapies, which is uncommon for patients with metastatic melanoma. Therefore, this population is discussed here separately.

30Cy/75Flu preconditioning in the ALL cohort did not yield deep neutropenia (online supplemental figure 3A). The lowest ANC value was $0.835 \pm 0.966 \mathrm{~K} / \mu \mathrm{L}$ (median $0.537 \mathrm{~K} / \mu \mathrm{L}) 9-11$ days after cell infusion. In addition, only a minor decrease in ALC was achieved (lowest values: $0.164 \pm 0.167 \mathrm{~K} / \mu \mathrm{L}$; median 0.367 , on day +1 ) (online supplemental figure 3B). Platelet counts were already low at baseline $(119 \pm 105 \mathrm{~K} / \mu \mathrm{L}$; median $95 \mathrm{~K} / \mu \mathrm{L}$ ) (online supplemental figure 3C). Baseline thrombocytopenia might be a result of leukemic infiltration of the bone marrow or extensive prior chemotherapy treatments. APCs were low, but unchanged from baseline and up to 3 months post therapy.

Comparing OR $(\mathrm{N}=13)$ and $\mathrm{NR}(\mathrm{N}=6)$ patients of the $30 \mathrm{Cy} / 75 \mathrm{Flu}$ cohort, there was no significant difference in ANC (OR vs NR; $d=1.380, p=0.053)$ and ALC $(\mathrm{d}=-0.246$, $\mathrm{p}=0.678$ ) (online supplemental figure 2D-E). APCs were significantly lower in non-responding ALL patients 1 day after NMA initiation and throughout the entire time of monitoring (OR vs NR; $\mathrm{d}=3.910, \mathrm{p}=0.001$ ) (online supplemental figure $3 \mathrm{~F}$ ). In both groups, APC was not affected by $30 \mathrm{Cy} / 75 \mathrm{Flu}$ lymphodepletion. Thus, the lower platelet counts in non-responding ALL patients seem disease dependent, rather than NMA related, which is in accordance with the existing literature. ${ }^{33}$

Patients stayed, on average, $23 \pm 8$ days in the hospital and received $1.0 \pm 1.4$ units of $\mathrm{RC}$ and $1.3 \pm 2.4$ units of PLT. Febrile neutropenia was observed in 12 of $19(63 \%)$ patients.

\section{DISCUSSION}

Lymphodepleting preconditioning is an integral part of all adoptive $\mathrm{T}$ cell therapies. However, to date, there is no 
guideline or standardization and no data, which compare different NMA regimens.

In this study, we compared different NMA therapies in regard to bone marrow suppression and recovery, cytokine serum levels, clinical response and adverse events.

We could demonstrate that 120Cy/125Flu and $60 \mathrm{Cy} / 125 \mathrm{Flu}$ preconditioning were equally efficient in achieving deep lymphopenia over a period of 1 week and deep neutropenia in patients with metastatic melanoma treated with TIL, whereas ALC and ANC were significantly higher following TBI/75Flu-induced NMA. In contrast, patients in the TBI/75Flu cohort had neutrophilia 1 day after cell infusion, followed by mild neutropenia. Acute thrombocytopenia was mainly observed in the 120Cy/125Flu cohort.

Despite the deep lymphopenia and neutropenia, patients in the $120 \mathrm{Cy} / 125 \mathrm{Flu}$ and $60 \mathrm{Cy} / 125 \mathrm{Flu}$ cohorts recovered within 6 days, whereas patients in the TBI/75Flu cohort recovered only after 1 month from their mild neutropenia.

The objective response rate in the $120 \mathrm{Cy} / 125 \mathrm{Flu}$ cohort was $28 \%$. Patients in the $60 \mathrm{Cy} / 125 \mathrm{Flu}$ and TBI/ Flu cohorts did not respond to TIL therapy. The lack of clinical efficacy in the $60 \mathrm{Cy} / 125 \mathrm{Flu}$ and TBI/Flu groups may have multiple reasons. Of note, patients in the latter two cohorts were all refractory to anti-PD1 immunotherapy compared with only 17 of 103 patients $(17 \%)$ in the $120 \mathrm{Cy} / 125 \mathrm{Flu}$ group. Interestingly, among the 17 anti-PD1 refractory patients in the $120 \mathrm{Cy} / 125 \mathrm{Flu}$ cohort, 16 patients did not respond to TIL therapy, which strengthens our hypothesis, that patients, refractory to anti-PD1 antibodies, are less likely to respond to TIL therapy compared with anti-PD1 naive patients.

To investigate if bone marrow suppression and recovery can serve as prognostic marker of clinical response and survival, we analyzed the cell counts in the $120 \mathrm{Cy} / 125 \mathrm{Flu}$ melanoma patient cohort. The analysis was performed on 29 responders and 74 non-responders. At baseline, there was no difference in absolute cell counts between responding and non-responding patients.

We could confirm that higher lymphocyte counts starting 4 days after cell infusion were significantly associated with clinical response. If the higher count reflects better engraftment and proliferation of infused $\mathrm{T}$ cells or a faster bone marrow recovery needs to be further investigated.

Previous studies have shown that the combination of cell counts, defined as inflammatory indexes, can serve as predictors of response. ${ }^{34-39}$ As anticipated, the PLR and NLR were lower in ORs from day 5 onwards.

ROC curve analysis 7 days after cell infusion was performed to determine the optimal cut-offs to distinguish between responding and non-responding patients and predict OS. Cut-offs were defined as NLR $\leq 1.79$ and PLR $\leq 32.7$. For example, $61 \%$ of patients with $P L R \leq 32.7$ responded to TIL therapy compared with $15 \%$ NRs $(\mathrm{p} \leq 0.001)$. The median OS was 39 months for patients with PLR $\leq 32.7$ and 12.5 months at PLR above 32.7.
Previous studies demonstrated that cytokine serum levels are associated with antitumor activity of the T cells and clinical response in patients undergoing adoptive $\mathrm{T}$ cell therapy. ${ }^{1819}$ Therefore, we compared the cytokine serum levels following the different NMA regimens. We could show that IL-15 levels were insignificantly different, TBI/75Flu-induced lymphodepletion resulted in significantly lower IL-7 serum levels and $60 \mathrm{Cy} / 125 \mathrm{Flu}-$ induced lymphodepletion resulted in significantly higher IL-21 serum levels compared with 120Cy/125Flu NMA. Since there were no differences between IL-7, IL-15 and IL-21 serum levels between overall responders and nonresponders in the $120 \mathrm{Cy} / 125$ Flu cohort, the clinical relevance of these findings is questionable.

We further analyzed the absolute cell counts of patients with relapsed or refractory ALL, who received a 30Cy/75Flu preparative regimen before CD19 CAR-T cell infusion. Only a minor decrease of ALC was observed. Although the contribution of leukemic blasts to ALC in patients with ALL cannot be absolutely excluded, it is very unlikely. Most patients were treated before had low or no circulating blasts at the time of lymphodepletion. ${ }^{31}$ Additionally, in the apheresis product, the starting material for CAR-T cell production, the total number of nonmalignant and malignant $\mathrm{B}$ cells was less than $5 \%$ in most patients and $0 \%$ in the CAR-T cell product. ${ }^{9}$

Furthermore, we investigated the impact of $30 \mathrm{Cy} / 75 \mathrm{Flu}-$ induced NMA on ANC and APC and could show that this regimen did not cause deep neutropenia and had no effect on APC.

Higher absolute platelet counts 1 day after NMA initiation (day -4) and throughout the entire time of monitoring were significantly correlated with clinical response. At baseline, there was a trend $(p=0.060)$ of a higher platelet count in OR patients. Prolonged event-free survival following CAR-T cell therapy was previously reported in patients with ALL with higher pre-lymphodepletion platelet count (32). Thus, it should be further investigated if APC assessment could be a helpful predictive marker to make clinical decisions in this patient population.

A major aspect that must be taken into account when choosing chemotherapy for lymphodepletion is the toxicity related to it. Patients in our $120 \mathrm{Cy} / 125 \mathrm{Flu}$ cohort developed significantly more acute adverse events, including thrombocytopenia, febrile neutropenia and cardiotoxicity. Thus, the time of hospitalization and the number of RC and PLT transfusions were significantly higher in this cohort. We reported three cases of acute cardiotoxicity following 120Cy/125Flu NMA. All three cases presented with symptoms of acute heart failure before TIL infusion and none of the patients suffered from cardiac problems before therapy. Of note, no other TIL trial reported cyclophosphamideinduced mortality, but, on the other hand, high-dose cyclophosphamide is known to cause cardiotoxicity in $7 \%-28 \%$ of patients. ${ }^{32}$ It was demonstrated that cyclophosphamide metabolites are responsible for cardiotoxicity due to depletion of antioxidants/ATP level, altered 
contractility, damaged endothelium and enhanced proinflammatory/proapoptotic activities resulting in cardiomyopathy, myocardial infarction and heart failure. ${ }^{32}$ Mortality has been reported in $11 \%-43 \%$ of patients at a dose of $170-180 \mathrm{mg} / \mathrm{kg}$. Halving the doses of cyclophosphamide from $60 \mathrm{mg} / \mathrm{kg}$ for 2 days (120Cy) to $30 \mathrm{mg} / \mathrm{kg}$ for 2 days $(60 \mathrm{Cy})$ might prevent this rare but severe adverse effect.

In summary, bone marrow suppression and recovery were equally effected by the $120 \mathrm{Cy} / 125 \mathrm{Flu}$ and $60 \mathrm{Cy} / 125 \mathrm{Flu}$ preconditioning in the melanoma cohorts; however, toxicity and consequently time of hospitalization were significantly lower in the $60 \mathrm{Cy} / 125 \mathrm{Flu}$ cohort. Patients in the 30Cy/75Flu ALL cohort and TBI/75Flu melanoma cohort rarely developed NMA-induced adverse events; however, both regimens were not efficient in achieving deep bone marrow suppression.

\section{Author affiliations}

${ }^{1}$ Ella Lemelbaum Institute for Immuno-Oncology, Sheba Medical Center at Tel Hashomer, Tel Hashomer, Israel

${ }^{2}$ Azrieli Faculty of Medicine, Bar-llan University, Safed, Israel

${ }^{3}$ Division of Pediatric Hematology and Oncology, The Edmond and Lily Safra Children's Hospital, Sheba Medical Center at Tel Hashomer, Tel Hashomer, Israel ${ }^{4}$ Department of Hematology, Tel Aviv University Sackler Faculty of Medicine, Tel Aviv, Israel

${ }^{5}$ Oncology Division, Sheba Medical Center at Tel Hashomer, Tel Hashomer, Israel ${ }^{6}$ Deparment of Clinical Microbiology and Immunology, Tel Aviv University, Sackler Faculty of Medicine, Tel Aviv, Israel

Acknowledgements The authors would also like to thank the Lemelbaum family for their generous support.

Contributors AN, SL-A, and MB designed the study. EJ, NA, GB, RS-F, JS, and GM recruited and treated the patients and are investigators. AN, SL, OI, EJ, and TM collected and analyzed the data. AN and TM performed the statistical analysis. AN, $\mathrm{SL}$, and MJ wrote the paper. All authors read and approved the final manuscript.

Funding The authors have not declared a specific grant for this research from any funding agency in the public, commercial or not-for-profit sectors.

Competing interests No, there are no competing interests.

Patient consent for publication Not required.

Ethics approval The study has been performed in accordance with the Declaration of Helsinki and was approved by the Israeli Ministry of Health. NCT numbers: NCT00287131 (TIL), NCT03166397 (TIL) and NCT02772198 (CAR-T). An informed consent to participate in the study was obtained from all participants or their legal guardian for minors.

Provenance and peer review Not commissioned; externally peer reviewed.

Data availability statement Data are available upon reasonable request.

Supplemental material This content has been supplied by the author(s). It has not been vetted by BMJ Publishing Group Limited (BMJ) and may not have been peer-reviewed. Any opinions or recommendations discussed are solely those of the author(s) and are not endorsed by BMJ. BMJ disclaims all liability and responsibility arising from any reliance placed on the content. Where the content includes any translated material, BMJ does not warrant the accuracy and reliability of the translations (including but not limited to local regulations, clinical guidelines, terminology, drug names and drug dosages), and is not responsible for any error and/or omissions arising from translation and adaptation or otherwise.

Open access This is an open access article distributed in accordance with the Creative Commons Attribution Non Commercial (CC BY-NC 4.0) license, which permits others to distribute, remix, adapt, build upon this work non-commercially, and license their derivative works on different terms, provided the original work is properly cited, appropriate credit is given, any changes made indicated, and the use is non-commercial. See http://creativecommons.org/licenses/by-nc/4.0/.
ORCID iDs

Nethanel Asher http://orcid.org/0000-0002-4094-8045

Michal J. Besser http://orcid.org/0000-0002-9233-0458

\section{REFERENCES}

1 Hirayama AV, Gauthier J, Hay KA, et al. The response to lymphodepletion impacts pfs in patients with aggressive nonHodgkin lymphoma treated with CD19 CAR T cells. Blood 2019;133:1876-87.

2 Besser MJ, Itzhaki O, Ben-Betzalel G, et al. Comprehensive single Institute experience with melanoma TIL: long term clinical results, toxicity profile, and prognostic factors of response. Mol Carcinog 2020;59:736-44.

3 Shapira-Frommer R, Schachter J. Adoptive immunotherapy of advanced melanoma. Curr Treat Options Oncol 2012;13:340-53.

4 Rosenberg SA, Dudley ME. Adoptive cell therapy for the treatment of patients with metastatic melanoma. Curr Opin Immunol 2009;21:233-40.

5 Dudley ME, Wunderlich JR, Robbins PF, et al. Cancer regression and autoimmunity in patients after clonal repopulation with antitumor lymphocytes. Science 2002;298:850-4.

6 Pedersen M, Westergaard MCW, Milne K, et al. Adoptive cell therapy with tumor-infiltrating lymphocytes in patients with metastatic ovarian cancer: a pilot study. Oncoimmunology 2018;7:e1502905.

7 Stevanović S, Draper LM, Langhan MM, et al. Complete regression of metastatic cervical cancer after treatment with human papillomavirus-targeted tumor-infiltrating T cells. $J$ Clin Oncol 2015;33:1543-50.

8 Stevanović S, Helman SR, Wunderlich JR, et al. A phase II study of tumor-infiltrating lymphocyte therapy for human papillomavirusassociated epithelial cancers. Clin Cancer Res 2019;25:1486-93.

9 Itzhaki O, Jacoby E, Nissani A, et al. Head-To-Head comparison of in-house produced CD19 CAR-T cell in all and NHL patients. $J$ Immunother Cancer 2020;8:e000148.

10 Dudley ME, Yang JC, Sherry R, et al. Adoptive cell therapy for patients with metastatic melanoma: evaluation of intensive myeloablative chemoradiation preparative regimens. $J$ Clin Oncol 2008;26:5233-9.

11 Wrzesinski C, Paulos CM, Kaiser A, et al. Increased intensity lymphodepletion enhances tumor treatment efficacy of adoptively transferred tumor-specific T cells. J Immunother 2010;33:1-7.

12 Gattinoni L, Powell DJ, Rosenberg SA, et al. Adoptive immunotherapy for cancer: building on success. Nat Rev Immunol 2006;6:383-93.

13 Salem ML, Cole DJ. Dendritic cell recovery post-lymphodepletion: a potential mechanism for anti-cancer adoptive T cell therapy and vaccination. Cancer Immunol Immunother 2010;59:341-53.

14 Klebanoff CA, Khong HT, Antony PA, et al. Sinks, suppressors and antigen presenters: how lymphodepletion enhances T cell-mediated tumor immunotherapy. Trends Immunol 2005;26:111-7.

15 Geukes Foppen MH, Donia M, Svane IM, et al. Tumor-Infiltrating lymphocytes for the treatment of metastatic cancer. Mol Oncol 2015;9:1918-35.

16 Antony PA, Piccirillo CA, Akpinarli A, et al. Cd8+ T cell immunity against a tumor/self-antigen is augmented by $\mathrm{CD} 4+\mathrm{T}$ helper cells and hindered by naturally occurring T regulatory cells. $J$ Immunol 2005;174:2591-601.

17 Gattinoni L, Finkelstein SE, Klebanoff CA, et al. Removal of homeostatic cytokine sinks by lymphodepletion enhances the efficacy of adoptively transferred tumor-specific CD8+ T cells. J Exp Med 2005;202:907-12.

18 Kochenderfer JN, Somerville RPT, Lu T, et al. Lymphoma remissions caused by anti-CD19 chimeric antigen receptor T cells are associated with high serum interleukin-15 levels. $J$ Clin Oncol 2017;35:1803-13.

19 Anthony SM, Rivas SC, Colpitts SL, et al. Inflammatory signals regulate IL-15 in response to Lymphodepletion. J Immunol 2016;196:4544-52.

20 Chen J-H, Zhai E-T, Yuan Y-J, et al. Systemic immune-inflammation index for predicting prognosis of colorectal cancer. World $J$ Gastroenterol 2017:23:6261-72.

21 Diao P, Wu Y, Li J, et al. Preoperative systemic immune-inflammation index predicts prognosis of patients with oral squamous cell carcinoma after curative resection. $J$ Transl Med 2018;16:365.

22 Zhong J-H, Huang D-H, Chen Z-Y. Prognostic role of systemic immune-inflammation index in solid tumors: a systematic review and meta-analysis. Oncotarget 2017;8:75381-8. 
23 Wang K, Diao F, Ye Z, et al. Prognostic value of systemic immuneinflammation index in patients with gastric cancer. Chin $\mathrm{J}$ Cancer 2017;36:75.

24 Wade RG, Robinson AV, Lo MCl, et al. Baseline neutrophillymphocyte and platelet-lymphocyte ratios as biomarkers of survival in cutaneous melanoma: a multicenter cohort study. Ann Surg Oncol 2018;25:3341-9.

25 Lino-Silva LS, Salcedo-Hernández RA, García-Pérez L, et al. Basal neutrophil-to-lymphocyte ratio is associated with overall survival in melanoma. Melanoma Res 2017;27:140-4.

26 Wang S, Ma Y, Sun L, et al. Prognostic significance of pretreatment neutrophil/lymphocyte ratio and Platelet/Lymphocyte ratio in patients with diffuse large B-cell lymphoma. Biomed Res Int 2018;2018:1-8.

27 Porrata LF, Ristow K, Habermann T, et al. Predicting survival for diffuse large B-cell lymphoma patients using baseline neutrophil/ lymphocyte ratio. Am J Hematol 2010;85:896-9.

28 Khoja L, Atenafu EG, Templeton A, et al. The full blood count as a biomarker of outcome and toxicity in ipilimumab-treated cutaneous metastatic melanoma. Cancer Med 2016;5:2792-9.

29 Finon A, Zaragoza J, Maillard H, et al. A high neutrophil to lymphocyte ratio prior to BRAF inhibitor treatment is a predictor of poor progression-free survival in patients with metastatic melanoma. Eur J Dermatol 2018;28:38-43.

30 Besser MJ, Shapira-Frommer R, Itzhaki O, et al. Adoptive transfer of tumor-infiltrating lymphocytes in patients with metastatic melanoma: intent-to-treat analysis and efficacy after failure to prior immunotherapies. Clin Cancer Res 2013;19:4792-800.

31 Jacoby E, Bielorai B, Avigdor A, et al. Locally produced CD19 CAR $T$ cells leading to clinical remissions in medullary and extramedullary relapsed acute lymphoblastic leukemia. Am J Hematol 2018;93:1485-92.

32 lqubal A, lqubal MK, Sharma S, et al. Molecular mechanism involved in cyclophosphamide-induced cardiotoxicity: old drug with a new vision. Life Sci 2019;218:112-31.

33 Hay KA, Gauthier J, Hirayama AV, et al. Factors associated with durable EFS in adult B-cell all patients achieving MRD-negative $\mathrm{Cr}$ after CD19 CAR T-cell therapy. Blood 2019;133:1652-63.

34 Jomrich G, Gruber ES, Winkler D, et al. Systemic immuneinflammation index (SII) predicts poor survival in pancreatic cancer patients undergoing resection. J Gastrointest Surg 2020;24:610-8.

$35 \mathrm{Hu}$ B, Yang X-R, Xu Y, et al. Systemic immune-inflammation index predicts prognosis of patients after curative resection for hepatocellular carcinoma. Clin Cancer Res 2014;20:6212-22.

36 Cho U, Park HS, Im SY, et al. Prognostic value of systemic inflammatory markers and development of a nomogram in breast cancer. PLoS One 2018;13:e0200936.

37 Wang $\mathrm{Y}$, Zhang $\mathrm{H}$, Yang $\mathrm{Y}$, et al. Prognostic value of peripheral inflammatory markers in preoperative mucosal melanoma: a multicenter retrospective study. Front Oncol 2019;9:995.

38 Robinson AV, Keeble C, Lo MCl, et al. The neutrophil-lymphocyte ratio and locoregional melanoma: a multicentre cohort study. Cancer Immunol Immunother 2020;69:559-68.

39 Capone M, Giannarelli D, Mallardo D, et al. Baseline neutrophilto-lymphocyte ratio (NLR) and derived NLR could predict overall survival in patients with advanced melanoma treated with nivolumab. $J$ Immunother Cancer 2018;6:74. 